IVM Institute for Environmental Studies

\title{
Are Dutch Water Safety Institutions Prepared for Climate Change?
}

Margo van den Brink $\square$

Catrien Termeer

Sander Meijerink

Report W-10/009

14 June 2010 
This report was commissioned by: Climate changes Spatial Planning

\author{
IVM \\ Institute for Environmental Studies \\ VU University Amsterdam \\ De Boelelaan 1087 \\ $1081 \mathrm{HV}$ Amsterdam \\ $\mathrm{T}+31-20-5989555$ \\ F +31-20-598 9553 \\ Einfo@ivm.vu.nl
}

\title{
Copyright $\odot$ 2010, Institute for Environmental Studies
}

All rights reserved. No part of this publication may be reproduced, stored in a retrieval system or transmitted in any form or by any means, electronic, mechanical, photocopying, recording or otherwise without the prior written permission of the copyright holder. 


\section{Contents}

$\begin{array}{lr}\text { Abstract } & 5\end{array}$

$\begin{array}{llr}1 & \text { Introduction } & 6\end{array}$

2 Method $\quad 8$

$2.1 \quad$ The Adaptive Capacity Wheel $\quad 8$

$\begin{array}{ll}2.2 & \text { Research protocol } \\ & 10\end{array}$

3 Results 13

$\begin{array}{lll}3.1 & \text { Assessing the Room for the River project } & 13\end{array}$

$\begin{array}{ll}3.2 & \text { Assessing the flood risk approach } \\ 3.3\end{array}$

$\begin{array}{lll}3.3 & \text { Assessing the Second Delta Plan } & 16\end{array}$

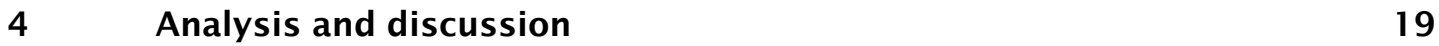

$\begin{array}{lll}4.1 & \text { Variety } & 19\end{array}$

$\begin{array}{ll}4.2 & 19\end{array}$

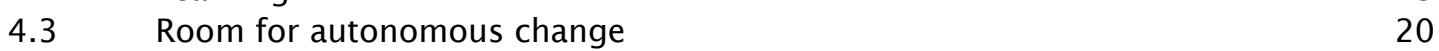

$\begin{array}{ll}4.4 & \text { Leadership } \\ 4.5 & 20\end{array}$

$\begin{array}{ll}4.5 & \text { Resources } \\ 4.6 & 21\end{array}$

$\begin{array}{lll}4.6 & \text { Fair governance } & 21\end{array}$

5 Conclusion $\quad 22$

$\begin{array}{lr}\text { Acknowledgements } & 24\end{array}$

$\begin{array}{lr}\text { References } & 25\end{array}$

$\begin{array}{llr}\text { Annex A } & \text { Authors contact details } & 28\end{array}$ 



\section{Abstract}

For the water sector, adapting to the effects of climate change is a highly complex issue. Due to its geographical position, the Netherlands is vulnerable to sea level rise, increasing river discharges, and increasing salt intrusion. This paper deals with the question to what extent the historically grown Dutch water safety institutions have the capacity to cope with the 'new' challenges of climate change. The Adaptive Capacity Wheel provides the methodological framework. The analysis focuses on three recent and major planning practices in the Dutch water safety domain: the development and implementation of the Room for the River project, the flood risk approach, and the Second Delta Plan, respectively. The results show that Dutch water safety institutions do enable climate change adaptation, but only to a limited extent. They face four important institutional weaknesses that may cause risks in particular on the long term. The paper concludes that for the Netherlands, to be prepared for climate change, it is necessary to take a new institutional path, by building capacity to improvise, by investing in and by creating room for collaborative leaders, and by finding ways to generate financial resources for long term innovative measures.

Key words: climate adaptation, water safety, institutions, capacity, the Netherlands. 


\section{Introduction}

Climate change is expected to bring about continuous and unpredictable changes to local weather patterns, water supplies and sea levels. Although many societies have a long record of managing the impacts of weather and climate, according to the Intergovernmental Panel on Climate Change (IPCC) additional adaptation measures are required to cope with in particular increasing flood risks (IPCC 2007). In reaction, countries all over the world are exploring the potential implications of climate change for the management of their water resources, and subsequently are developing new and innovative strategies and measures to anticipate these implications (e.g. Arnell 1998; Tanaka et al. 2006, see for an overview also Huitema \& Meijerink 2009; Ludwig et al. 2009). Due to its geographical position in the delta of the Rhine, Scheldt and Meuse rivers, the Netherlands is particularly vulnerable to sea level rise, increasing river discharges, and increasing salt intrusion. Besides the development of traditional technical measures, such as dikes, dams and storm surge barriers, Dutch water managers are now also trying to develop and implement new modes of flood risk management.

For the water sector, adapting to the effects of climate change is a highly complex issue (Bohensky \& Lynam, 2005; Raadgever et al. 2008; Huitema \& Meijerink 2009; Ludwig et al. 2009). There are many uncertainties about the magnitude and potential impacts of climate change, and about the effectiveness and feasibility of adaptation strategies. Moreover, climate change, its potential impacts and the various possible adaptation strategies are interpreted and framed differently by the parties involved. Because of these uncertainties and ambiguities, it is generally acknowledged that climate adaptation requires a high adaptive capacity of society (e.g. Gupta et al. 2008, Forthcoming; Huitema et al. 2009). As we do not know beforehand which course of action is the most effective, we need to be able to experiment with different strategies, to learn from experiences gained, and to adjust our policies and strategies to changing circumstances.

It is generally known that the Netherlands has a long history of coping with water safety (see e.g. Lintsen 2002; Huisman 2004; van de Ven 2004). At first, the Dutch learned to reduce flood vulnerability by building their houses on mounds. Later on they started to build small dikes to protect their houses and land, and they recognised the need for collective action to construct and maintain these dikes. In the course of time, due to experiences gained and technological progress made, the quality of the dikes improved greatly. In addition, the ongoing centralisation and technocratisation of flood protection made possible the realisation of various large-scale coastal engineering projects, among which the damming of the Zuiderzee and the construction of the Delta Works (Lintsen 2002).

Dutch water safety institutions are thus the product of times in which the climate issue, as we now know it, was hardly of any importance. This paper therefore deals with the question to what extent the historically grown Dutch water safety institutions have the capacity to cope with the 'new' challenges of climate change. Inspired by Scott (2008), we define institutions as cognitive, normative and regulative structures that provide stability and meaning to social behaviour. Institutions enable and constrain the opportunities of actors to respond to changes in their environment. Moreover, they can be formal and formal, and they can be created or simply evolve over time (North 1990; March \& Olson 1989). Formal institutions can include laws, 
official policies, and organisational structures. Informal institutions can include routine practices and ways of doing things.

In what follows, we first present a method to asses the capacity of institutions to enable adaptation: the Adaptive Capacity Wheel (see also Gupta et al. 2008, Forthcoming). Subsequently, with the help of this method we assess the capacity of Dutch water safety institutions to deal with the new challenges of climate change. For this purpose, we analyse three recent and innovative practices in the Dutch water safety domain: the development and implementation of the Room for the River project, the flood risk approach, and the Second Delta Plan, respectively. We conclude this paper with a reflection and conclusions on the extent to which Dutch water safety institutions are prepared for climate change. 


\section{Method}

\subsection{The Adaptive Capacity Wheel}

To assess the capacity of institutions to enable climate change adaptation, we have developed the Adaptive Capacity Wheel (see Figure 2.1). We have distinguished six qualities of institutions: three core qualities, namely variety, learning, and the room for autonomous change, and three supporting qualities, namely leadership, resources, and fair governance (see Gupta et al., 2008, Forthcoming, for an extensive overview and theoretical underpinning of this Wheel). Subsequently, to assess these qualities, we have developed 22 criteria. Together, the six qualities and 22 criteria form the Adaptive Capacity Wheel.

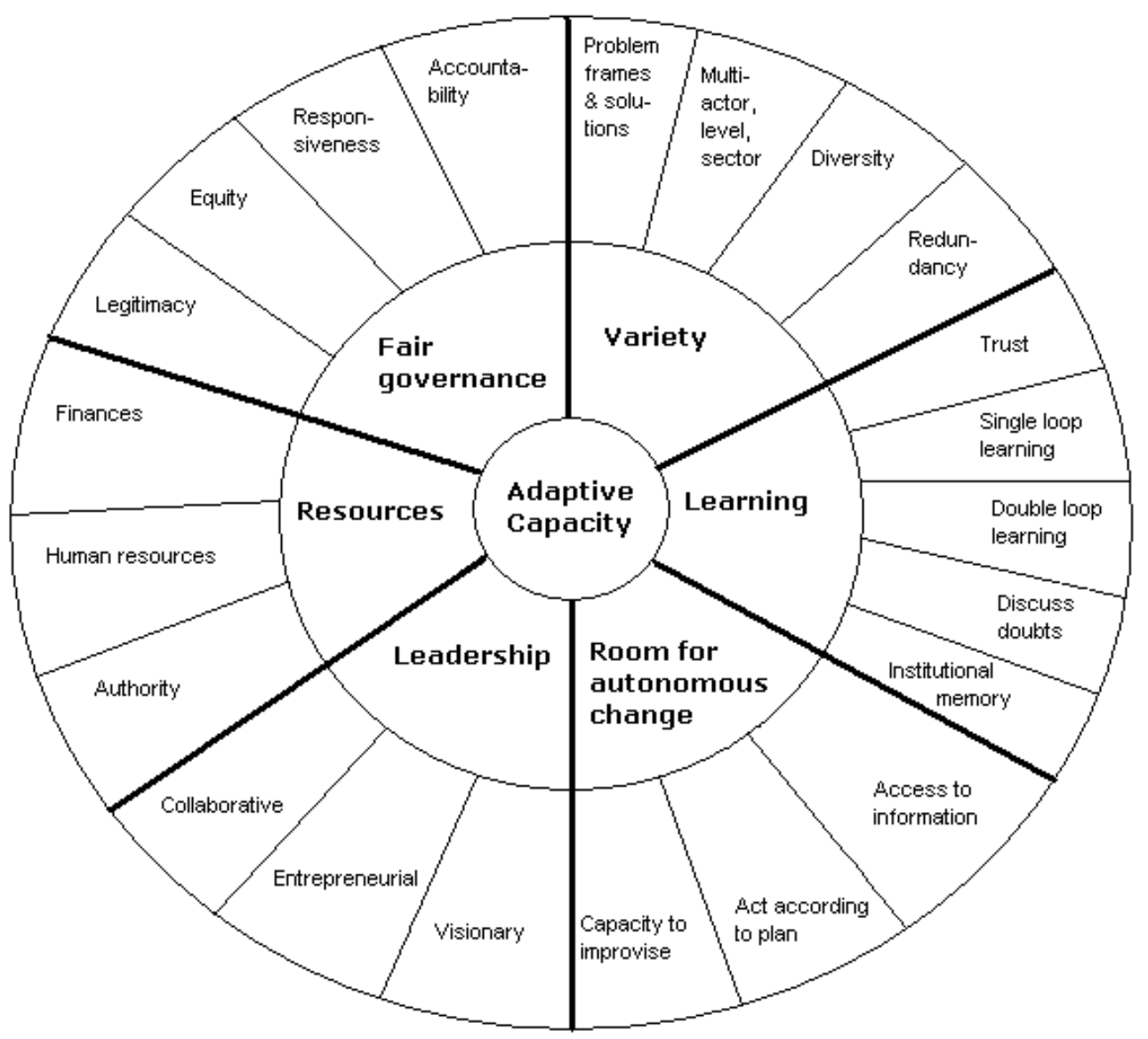

Figure 2.1 The Adaptive Capacity Wheel.

\subsubsection{Variety}

The first core quality refers to the idea that the variety within a system must be at least as great as the environmental variety against which it is attempting to adjust itself (Conant \& Ashby 1970). To deal with the manifold uncertainties and ambiguities of the climate issue, it is often argued that it is important to allow for and encourage variety (e.g. Verweij \& Thompson 2006; Pahl-Wostl et al. 2007; Weick \& Sutcliffe 2001).

Societies have to be preoccupied with keeping sufficient diversity inside, to be able to sense accurately the variety in ecological change outside. Not only variety in developed 
ideas and policy measures is required, thus variety on paper or in policy formulation, but also variety in realised adaptation strategies, thus variety in planning practice and policy implementation. The extent to which institutions allow for and encourage variety is indicated by the following criteria: the involvement of a variety of policy frames and solutions; the involvement of a variety of actors, sectors, and administrative levels during policy making and implementation; the room to promote a differentiation of adaptation strategies; and redundancy. Redundancy implies 'more of the same', for example the development of back up measures for a reduction of the flood probability.

\subsubsection{Learning}

The second core quality is learning. The climate issue is not only characterised by uncertainties about the effects of climate change, but also by uncertainties about how we should anticipate these effects. In each specific case, the parties involved face the challenge of discovering together the 'best' adaptation strategy. Moreover, the climate issue is a relatively new issue. It is therefore likely that it will conflict with dominant values, routines and problem frames and solutions. To deal with the uncertainties and the newness of the climate issue, it is often argued that an institutional setting is required that stimulates and supports learning (e.g. Pahl-Wostl et al. 2007; Dewulf et al. 2005). Ideally, actors exchange their problem frames and together make sense of the issues at stake, while at the same time discussing doubts (Weick \& Sutcliffe 2001). Moreover, they are able and willing to scrutinise their underlying assumptions, and engage in single loop learning (i.e. improving routines) and double loop learning (i.e. challenging norms and basic assumptions) (Argyris \& Schön 1978). The extent to which institutions allow for and encourage learning is thus indicated by the following criteria: trust, single and double loop learning, the possibility to discuss doubts and an institutional memory.

\subsubsection{Room for autonomous change}

The third core quality of adaptive institutions is the room for autonomous change. Due to the unpredictable nature of many climate change effects, this is an important quality. It is about the capability of actors to improvise during crises at all levels of society, and to act as accommodating to and experimenting with the everyday contingencies, breakdowns, exceptions, opportunities and unintended consequences (Orlikowski 1996). The degree to which institutions allow for and encourage the room for autonomous change is indicated by the following criteria: the access to information about potential climate change impacts, the capacity of actors to improvise, and their ability to act according to plan.

\subsubsection{Leadership}

The fourth quality of institutions, leadership, supports the first three core qualities. Crucial are people in the public domain that promote change actively, and who face challenges by seeing opportunities, arranging connections and by reinterpreting their own routines. In this context, the following three types of leadership are particularly important. First, visionary leadership is important to link different time scales and to convince others to anticipate potential future threats (Young 1991). Second, entrepreneurial leadership is necessary to gain access to the necessary resources for realising adaptation projects (Andersson \& Mol 2002; Termeer 2009). And third and finally, collaborative leadership is necessary to bridge gaps, span boundaries, and build coalitions (Huxham \& Vangen 2005). 


\subsubsection{Resources}

The availability of resources also supports the three core qualities of institutions. For adaptation efforts to succeed, it is crucial that actors are able to generate sufficient resources (Biermann 2007). First, financial resources are required to experiment with and implement adaptation strategies. Next, human resources - such as knowledge and expertise - are required to develop these adaptation strategies. Finally, authority is required to take and implement the necessary decisions.

\subsubsection{Fair governance}

The sixth and final quality also supports the three core qualities of institutions. It is crucial that institutions meet fair governance criteria and can deal with social justice dilemmas (Paavola \& Adger 2006). As we emphasise redundancy over costeffectiveness, we prefer the phrase 'fair governance' rather than the dominant phrase of 'good governance' (e.g. Botchway 2001). Institutions should allow for and encourage responsive and accountable policy making and implementation. In addition, they should protect basic rights and equity and promote legitimate policy processes.

\subsection{Research protocol}

The Adaptive Capacity Wheel cannot be 'objectively' applied and will always be subject to expert judgement and good interpretation. For such a qualitative tool to have scientific relevance, it is important that it is transparent and that its application by different researchers leads to consistent results. For this reason, we have developed a research protocol to apply the Adaptive Capacity Wheel (see Gupta et al. Forthcoming), consisting of five subsequent steps: (1) preparing for the research; (2) collecting the data; (3) analysing the data; (4) interpreting the data; and (5) communicating and presenting the data. In the remainder of this section, we briefly explain how we have made use of these steps for our analysis of Dutch water safety institutions.

\subsubsection{Step 1: preparing for the research}

To demarcate our object of study, the Dutch water safety domain, we decided to analyse three recent planning practices, namely the development and implementation of the Room for the River project, the flood risk approach, and the Second Delta Plan, respectively. The Room for the River project aims at improving the water safety of the Dutch riverine area through creating more space for the water. It is an important example of the development of spatial measures to reduce the flood probability. In addition, Dutch water managers now also try to introduce a flood risk approach 'flood risk' is defined as the probability of a flood times the potential impact of flooding - and develop policies to reduce the potential impacts of flooding. Careful planning of evacuation routes, developing early warning systems, and adapting houses and infrastructure to prepare urban areas better for flooding are some examples. Finally, to anticipate the projected effects of climate change, in 2007 a state committee was established to develop a more general and coordinating course of action to 'climate-proof' the Netherlands. In September 2008, this 'Second Delta Committee' - the first one was established after the flood disaster of 1953 and induced the construction of the large scale Delta Works - published its advice 'Working together with water: a land that lives is building its future' (Deltacommissie 2008), also referred to as the 'Second Delta Plan'. Together, these three practices represent the most important recent developments in the Dutch water safety policy domain. For this 
reason, we assumed that they can best inform us about the extent to which Dutch water safety institutions enable climate change adaptation.

\subsubsection{Step 2: collecting the data}

Subsequently, we decided to make use of the following three data sources: 1) various types of documents, such as newspaper articles, press releases and policy reports; 2) previous extensive research of the authors, based on a large amount of semistructured interviews and participatory observations (e.g. van den Brink \& Meijerink, 2006; Meijerink \& Dicke, 2008; Huitema \& Meijerink, 2009; Termeer \& Meijerink, 2009; van den Brink, 2009); and 3) analyses of existing accounts of current developments in the Dutch water safety policy domain (e.g. Wiering \& Driessen 2001; Disco 2002; van der Brugge et al. 2005; Wiering \& Immink 2006; Woltjer \& Al 2007; Hidding \& van der Vlist 2009). Together, these three data sources provided sufficient material to assess the capacity of Dutch water safety institutions to deal with the climate issue.

\subsubsection{Step 3: analysing the data}

The next step of our research protocol involved the qualitative analysis of the data that we had collected, that is, the 'scoring' of the six central qualities and 22 criteria of the Adaptive Capacity Wheel. This step of the research consisted of three subsequent phases. First, on the basis of the data sources described above, we scored the qualities and criteria ourselves, after which we asked the other members of our project team ( 8 in total, including ourselves), who are also familiar with the water sector, to judge and improve our analysis. Third, we organised several workshops with key stakeholders within the Dutch water safety domain, during which the results of our analysis were critically discussed and reflected upon, and we presented and discussed our analysis at several conferences (e.g. Termeer 2010) and workshops at among others interested consultancy firms (e.g. Meijerink 2008). In this way, we created room to discuss differences of opinion, if any, on a specific quality or criterion. In addition, special attention was paid to the registration of the underlying arguments leading to a specific score. A colour scheme (from green to red - see Figure 2.2) was used to visualise the results of our analysis and to facilitate the comparison between the three water management practices. The numbers were used to aggregate the scores of the various criteria.

\begin{tabular}{|l|c|c|}
\hline \multicolumn{1}{|c|}{ Effect of institutions on adaptive capacity } & Score & $\begin{array}{c}\text { Aggregated scores for the six qualities } \\
\text { and the adaptive capacity as a whole }\end{array}$ \\
\hline Positive effect & +2 & +1.01 to +2.00 \\
\hline Slightly positive effect & +1 & +0.01 to +1.00 \\
\hline Neutral or no effect & 0 & 0.00 \\
\hline Slightly negative effect & -1 & -0.01 to -1.00 \\
\hline Negative effect & -2 & -1.01 to -2.00 \\
\hline
\end{tabular}

Figure 2.2 The colour scheme that was used to score the qualities of the Adaptive Capacity Wheel. 


\subsubsection{Step 4: interpreting the data}

After the data analysis, the scores and colours were related and interpreted in a broader context. This step also included the explanation of dependencies between the qualities and criteria, and the comparison of the three cases. Data were translated into stories to communicate the strengths and weaknesses of the assessed institutions.

Finally, during this step we drew conclusions on the capacity of the Dutch water safety institutions to promote adaptation to climate change, and we reflected on what could be done to improve this capacity.

\subsubsection{Step 5: communicating and presenting the data}

The last and final step concerned the communication and presentation of the data. Besides the workshops that were organised to critically discuss and improve our findings and our presentations at conferences and workshops, we decided to use colours rather than grey shades to communicate how well a criterion or quality scores (see Figure 2.2). Whereas a grey tone is non-judgemental and provides a more neutral evaluation, a traffic light system - where green symbolises a high score and red a low score - is more communicative. By presenting the institutional strengths and weaknesses that we discovered in this way, we also aimed to suggest where there might be room for reform. 


\section{Results}

In this section, with the help of the Adaptive Capacity Wheel, we show the results of our assessment of the capacity of the institutions involved in the development and implementation of the Room for the River project, the flood risk approach and the Second Delta Plan respectively, to enable climate change adaptation. For an explanation of the colours, see Figure 2.2.

\subsection{Assessing the Room for the River project}

The basic idea of the 'room for the river' safety concept is to enlarge the discharge capacity of the main Dutch rivers by increasing the amount of space for the rivers (Wiering \& Driessen 2001). The main aim of the national Room for the River project, which was formally introduced in 2002, was to develop and implement a coherent river-widening plan for the Rhine River and its branches Waal, Nederrijn-Lek and IJssel. The first objective was to realise the water safety of the about 4 million inhabitants of the Dutch riverine area. The second objective was to improve the spatial quality of the river landscape (Ministerie van Verkeer en Waterstaat et al. 2002). The initiating ministries were the Ministry of Transport, Public Works and Water Management (main initiator), the Ministry of Housing, Spatial Planning and the Environment, and the Ministry of Agriculture, Nature and Food Quality. The central project organisation was established at Rijkswaterstaat, the policy-implementing agency of the Ministry of Transport, Public Works and Water Management, and generally valued for its ability 'to get things done' and for its knowledge and expertise about the river system. Besides being the main initiator, this ministry brought in by far the most financial resources for implementing the river-widening measures. 


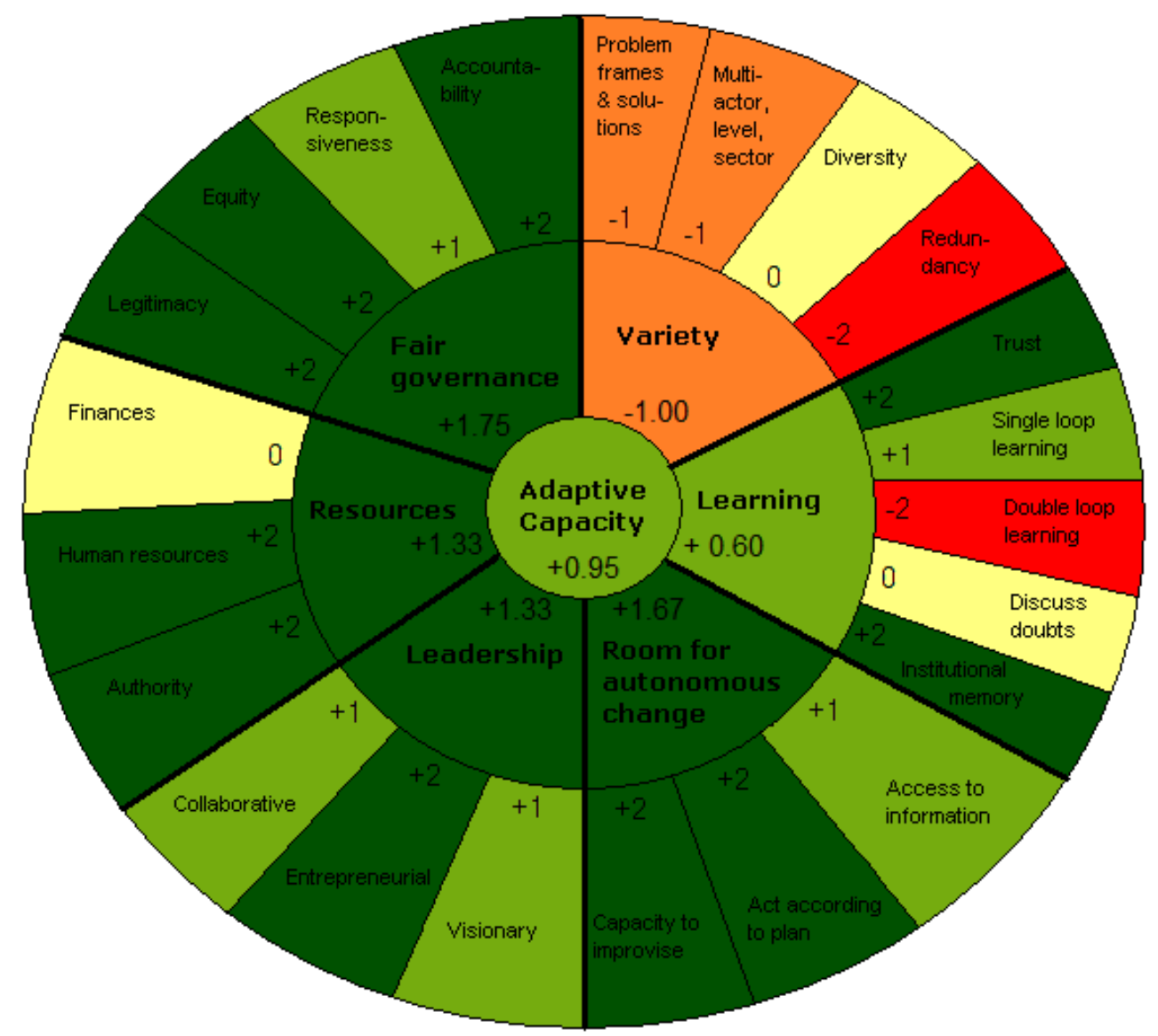

Figure 3.1 The Adaptive Capacity Wheel applied to the Room for the River project.

Figure 3.1 visualises the results of our assessment of the capacity of the water safety institutions involved in the development and implementation of the Room for the River project. Interestingly, at first sight, the outcome of our assessment seems quite positive. In particular the supporting qualities of institutions - leadership, resources, and fair governance - 'score' relatively well. Only the financial budget for the Room for the River project was rather limited, inducing a search for the most cost-effective packages of measures. As a result, a redundancy of measures was not promoted, and some favourable and preferred long term spatial measures were substituted for short term technical measures, because they were too expensive. The institutions also allowed for and promoted continuous learning (see also Meijerink 2004). For instance, substantive learning was stimulated by the development and introduction of a Decision Support System. This 'Planning Kit' (Blokkendoos) consisted of around 600 possible river-widening measures and enabled the parties involved to learn about the impact that various combinations of policy measures would have on the water levels in the main rivers. The initiating ministries also showed capacity to improvise. During the project, the organisational structure and the corresponding division of roles and responsibilities gradually developed, combining central and decentralised steering in various innovative ways. From the local through to the national level there was space for informal networks of actors who self-organised to solve problems (e.g. Hufen \& Lotze 2004).

However, our assessment also showed that the degree to which the institutions allow for and encourage the core quality of in particular variety is rather limited. Here there clearly is a tension between the institutions and the adaptation-needs. Although both 
technical and spatial measures were developed and implemented to reduce the flood probability, measures and strategies to reduce the potential impacts of flooding, and which address the whole safety chain from flood prevention and evacuation and even after care, were not included. In addition, only government authorities (ministries, provinces, municipalities and water boards) and parties from civil society (NGOs and inhabitants) were involved. Private parties ('the market') were not asked to participate. Subsequently, conflicting problem perceptions between water managers and spatial planners hindered the development and implementation of the more spatial riverwidening measures. The dominant problem frame was the necessity to realise the water safety of the inhabitants of the riverine area, rather than improving its spatial quality.

\subsection{Assessing the flood risk approach}

In addition to the development of new and more spatial modes of flood protection, Dutch water managers now also try to develop and implement policies to reduce the potential impacts of flooding. The flood risk approach was introduced formally in the 'Draft Policy Document on Water Safety', which was published in 2008 (Rijksoverheid 2008), and for the first time aimed to address the whole 'safety chain', from flood prevention to evacuation and even aftercare (see also Meijerink \& Dicke 2008). The concept of 'multi-layered safety' was introduced to make a distinction between three different safety layers. The first and most important layer is flood prevention: the reduction of the flood probability and the implementation of the safety standards by taking technical and spatial measures. The Ministry of Transport, Public Works and Water Management is primary responsible for the realisation of this safety layer. The second layer involves sustainable and 'climate-proof' spatial planning on the basis of 'flood risk maps' and the 'water assessment'. The Ministry of Housing, Spatial Planning and the Environment is primary responsible for this layer; water managers only have an advisory role. The third and final safety layer of the Draft Policy Document on Water Safety involves disaster management, for which the Ministry of the Interior and Kingdom Relations is primary responsible. Despite flood prevention and sustainable spatial planning, a flood disaster always forms a threat that has to be anticipated. To reduce the number of casualties and the economic damage, it is necessary to develop strategies of disaster management. 


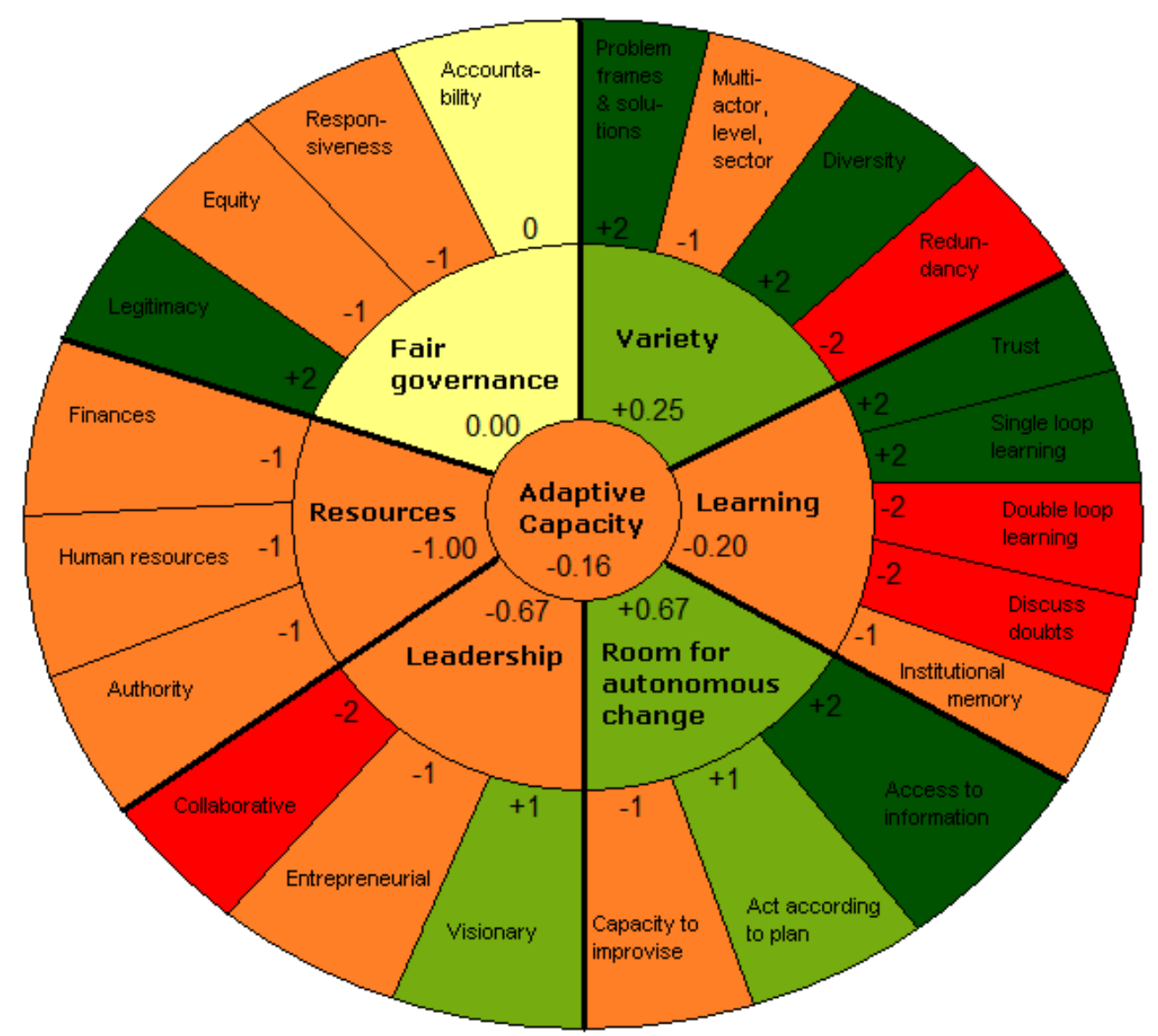

Figure 3.2 The Adaptive Capacity Wheel applied to the flood risk approach.

Figure 3.2 depicts the results of our assessment of the capacity of the water safety institutions concerned with the development and implementation of the flood risk approach. The overall picture here is far less optimistic than it was for the Room for the River project. The institutions obviously experience severe difficulties with allowing for and encouraging the core qualities as well as the supporting qualities of the Adaptive Capacity Wheel. Although with the introduction of the flood risk approach and concepts such as the 'safety chain' and 'multi-layered safety', a large variety of problem frames has been introduced in the water safety policy domain and, consequently, a large variety of potential solutions and measures has been developed, flood prevention is still considered the most important safety layer. Until now, measures to reduce the flood vulnerability are hardly implemented. The flood prevention layer is even referred to as the core or even the 'corner stone' of Dutch water safety policy (DG Water 2008). Sustainable spatial planning and disaster management are viewed as supplementary measures, for which other parties than the Ministry of Transport, Public Works and Water Management are primary responsible. In addition, flood risk management is still mainly a public issue, focusing on flood prevention, for which the Ministry of Transport, Public Works and Water Management carries the primary responsibility.

\subsection{Assessing the Second Delta Plan}

The main aim of the Second Delta Plan, entitled 'Working together with water: A land that lives is building its future' (Deltacommissie 2008), is to protect the Netherlands 
against the effects of climate change and to make the country climate-proof for the long term, while it remains an attractive place to live and invest in. The Second Delta Plan has been developed by a state committee, also referred to as the 'Veerman Committee' after its chair Cees Veerman, a former Minister of Agriculture, Nature and Food Quality. The members of the Delta Committee included a well known economist, civil engineer, climate system expert, landscape architect, and the director of a large dredging company. To determine the climate scenario that would function as the general starting point and the main contours of the plan, the committee asked advice of numerous scientific experts. Only in the concrete planning and implementation phase of the Delta Plan, other parties (e.g. national, regional and local government authorities, NGOs and involved citizens) will be involved.

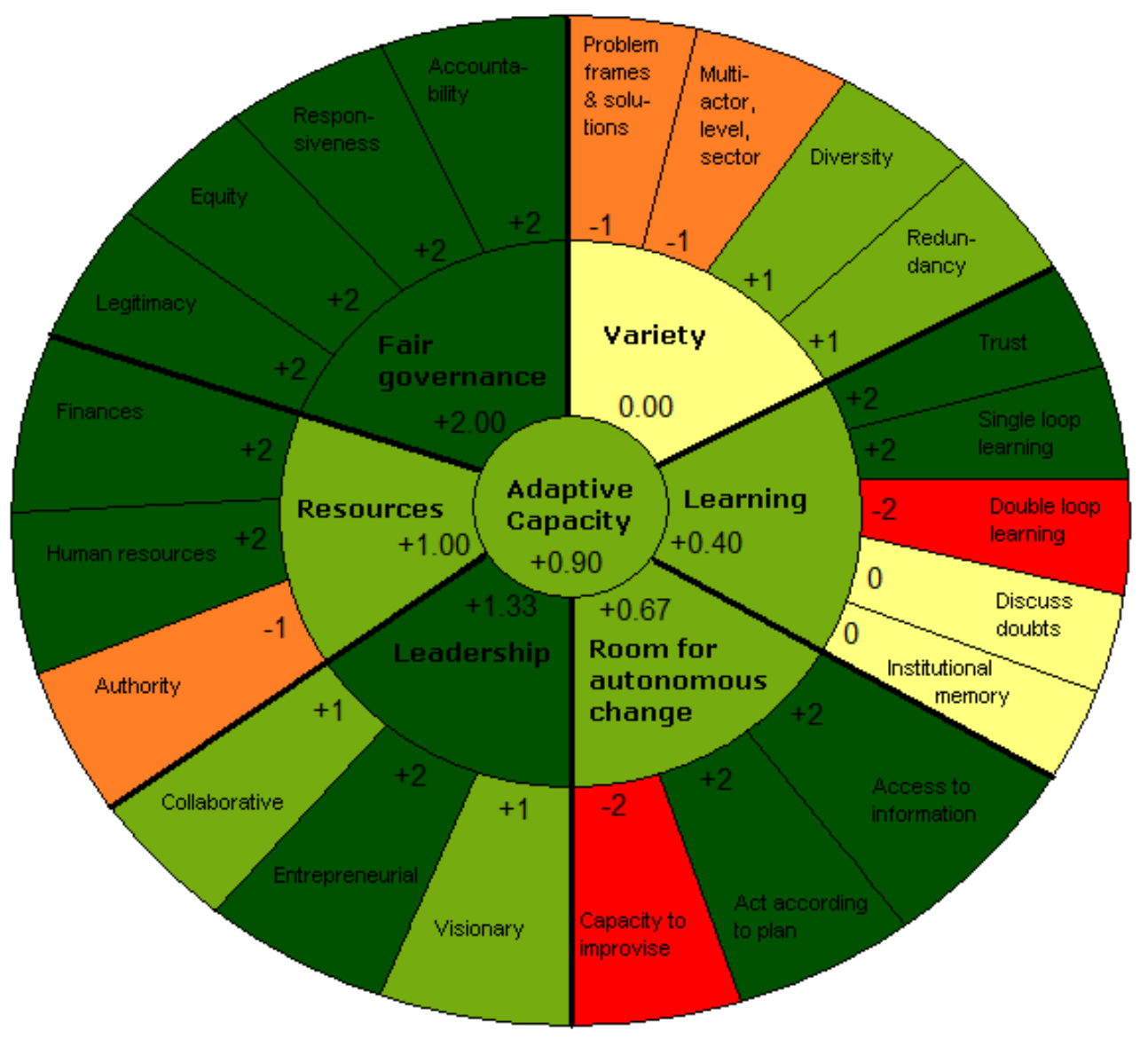

Figure 3.3 The Adaptive Capacity Wheel applied to the Second Delta Plan.

Figure 3.3 visualises our assessment of the capacity of the water safety institutions involved in the development and implementation of the Second Delta Plan. The overall picture here is neither completely negative nor completely positive. To begin with, although the Committee followed the recently introduced flood risk approach, and aimed to make the Netherlands climate-proof by reducing both the probability and the potential impacts of flooding, it also stated explicitly from the beginning that it would primarily focus on flood prevention, as that had proven to be the most effective strategy in the past (Deltacommissie 2008: 41). Sustainable spatial planning and measures to reduce the impacts of flooding were viewed merely a as supplementary or additional problem solution, that is, as alternative back up measures, and therefore were not made part of the plan. The same applied to disaster management strategies. 
In this way, the Delta Committee plead for a redundancy in measures: measures for vulnerability reduction were stimulated next to, rather than instead of, measures for probability reduction. After its name and reference to the well known Dutch Delta Works, and like its predecessor, the Second Delta Plan thus mainly focused on taking measures to reduce the flood probability. The Second Delta Committee even proposed to increase the safety standards by at least a factor ten. However, although the focus was only on flood prevention, the variety of (both developed and implemented) measures to reduce the probability of flooding increased greatly. In particular, the committee invested in developing new and innovative technologies and technical measures to fight the water. For instance, the concept of the 'Delta Dike' was introduced. Delta Dikes are that high, that broad or that strong, so that the probability of unexpected and uncontrollable flooding is practically zero.

For the implementation of the Second Delta Plan, the Committee advised to establish a 'Delta Programme'. The implementation of the Delta Programme will be supported by a 'Delta Fund' - from 2020 every year one billion Euros will be made available for measures such as raising and strengthening the dikes - and politically and organisationally by a 'Delta Act'. Furthermore, following the example of the Room for the River project, the Delta Programme will provide for a connecting central coordination on the one hand, by the 'Delta Coordinator', and local and regional responsibility for the implementation of the separate projects on the other hand. 


\section{$4 \quad$ Analysis and discussion}

\section{1 Variety}

Traditionally, the established institutions for water safety hinder the development and implementation of a variety of policy options. Dutch water safety policies are primarily aimed at 'fighting the water', at flood prevention, by building and strengthening dikes, dams and other flood defences. Nevertheless, the past years the variety particularly in developed ideas and policy measures for climate adaptation has increased greatly. First, various new technologies have been introduced to reduce the flood probability. An important example is the 'Delta Dike'. Second, in addition to the introduction of these new technical measures, various spatial measures have been developed to reduce the flood probability, such as the spatial river-widening measures of the Room for the River project. Third, besides by taking technical and spatial measures to reduce the flood probability, various policy measures have been developed to reduce the potential impacts of flooding, addressing the whole safety chain.

However, although the last years a large variety of problem frames and potential solutions and measures has been developed, the actual implementation of these measures remains problematic. The same is true for the inclusion of other parties than governmental authorities in the development of these measures. The Dutch government still explicitly and primarily focuses on flood prevention - the reduction of the flood probability - as that has proven to be the most effective strategy in the past (Deltacommissie 2008: 41). This is also the dominant perspective of the Second Delta Plan. Measures for vulnerability reduction were only stimulated next to, rather than instead of, measures for probability reduction. A redundancy in measures was only promoted with regard to flood prevention.

\subsection{Learning}

In line with the focus of the Dutch government on flood prevention, continuous learning still mainly takes place on the existing institutional path, which can be interpreted as single loop learning. Reinterpreting and changing existing routines and taking a new institutional path, also referred to as double loop learning, turns out to be rather difficult. Although various new and innovative policy strategies have been developed, such as in particular the strategies to reduce the potential impacts of flooding and the strategies to create more room for water, conflicting problem frames hinder the actual implementation of these strategies (van den Brink \& Meijerink 2006).

In general, for Dutch water managers, water safety should always come first. Without flood protection, the Netherlands would be much smaller, and many land use functions would not be possible. In line with this conviction, Room for the River for instance was considered a crucial project: the only way of guaranteeing safety for the about 4 million inhabitants of the riverine areas was by increasing the discharge of the main rivers. As most spatial planners are used to balance interests, for them water is just one of the ordering principles of spatial planning. It is one of the many claims on the scarce space. Other land use functions, such as housing, agriculture, nature development and recreation are equally important. Hence, for spatial planners, Room for the River was just one of the many relevant developments. Spatial planners wanted to cooperate in the Room for the River project, primarily to improve the spatial quality of the river landscape. They often opposed the traditional technical measures, and 
generally were enthusiastic about the creation of river bypasses and the replacement of dikes.

\subsection{Room for autonomous change}

The water safety institutions allow actors continuous access to information on the impacts of climate change, and enable them to make adjustments in project plans and governance structures. The programmatic approach of the Room for the River project and its continuously changing organisational structure and the corresponding division of roles and responsibilities are some good examples (Hufen \& Lotze, 2004; ten Heuvelhof et al., 2007).

However, the capacity to improvise remains rather underdeveloped. The Second Delta Plan emphasises that flood safety will continue to be a public interest, for which the central government has - and will continue to have - the primary responsibility (Deltacommissie 2008: 89). Private parties are only invited to invest in or co-finance measures when their interests can be realised at the same time. As a result, it is likely that the 'control paradox' (Remmelzwaal \& Vroon 2000) will remain to exist and will even increase. Flood prevention measures encourage more intensive land use behind the dikes (because people feel safer). Hence, when there is a flood disaster, there will be more damage and people will have a strong feeling of being at risk. This provides an impetus to raise and strengthen the dikes again. The strategy of developing and implementing flood prevention measures thus creates a vicious circle, because these measures do not take away the cause of the problem and in fact even create new risks (Wiering \& Immink 2006). As people feel safe behind dikes and trust that the government will take care of them, they will not develop the capability (i.e. knowledge and authority) to improvise at times of crisis.

\subsection{Leadership}

The Dutch Ministry of Transport, Public Works and Water Management, and in particular Rijkswaterstaat, its policy-implementing agency, are generally valued for their ability 'to get things done' and for their ability to lead by taking action - that is, for their entrepreneurial leadership (van den Brink 2009). For several decades now, Dutch water managers succeeded in protecting the Netherlands against floods. They have initiated the Room for the River project, developed new and innovative flood protection measures, and suggested to appoint a 'Delta Coordinator' to implement the water safety measures that are part of the Second Delta Plan. The Second Delta Committee in particular has demonstrated visionary leadership, that is, its ability to connect different time scales and create a sense of urgency. Moreover, the chair of the Committee has played an important role in putting the climate issue on the Dutch political and societal agenda.

However, the vision that was presented was one-sided, focusing on flood prevention rather than the reduction of the potential impacts of flooding. One important reason for the one-sidedness of the Second Delta Plan and the still very marginal implementation of the flood risk approach is the fear that more attention for vulnerability reduction may come at the cost of attention for flood prevention. For this reason, the development and institutionalisation of a more collaborative leadership style is not stimulated. The new forms of project and programme management, in which hierarchical and decentralised steering are combined in networks and alliances of different parties, only developed very gradually and because of the increasing 
interdependencies in the Dutch water policy domain. Dutch water managers still generally belief that only by separating tasks and responsibilities with regard to water management and spatial planning, water safety norms can be realised. The fear is that when the safety norms are made part of integrated, interactive and decentralised planning processes, water safety could come off worst. The current national debates on the potential discontinuance of the water boards and merge of the Ministry of Transport, Public Works and Water Management and the Ministry of Housing, Spatial Planning and the Environment are exemplary for the difference of opinion between water managers (who generally oppose these reforms) and spatial planners (who generally support these reforms). Hence, the dominant focus on probability reduction rather than the lack of leadership skills is the issue.

\subsection{Resources}

Although the Ministry of Transport, Public Works and Water Management possesses unique institutional arrangements to generate the necessary resources for water safety, these resources, in particular the financial budget for the development and implementation of adaptation strategies, are also highly dependent on the political and public climate. In this respect, important complicating factors are the dominant focus on the development of cost-effective packages of measures and the low water awareness of Dutch society, as a result of which there is always a danger that the budget that is needed to maintain water safety is allocated to other - more appealing purposes, such as public health or education. It is exactly for this reason that the Second Delta Committee has recommended the establishment of a 'Delta Fund'. Although the Dutch government has recently approved a proposal for such a fund, which guarantees that 1 billion euro will be made available yearly as from 2020, it remains to be seen how this idea will be implemented in practice. The latest plans are to make the Delta Fund a specific part of the existing investment budget for infrastructure, and it is yet unclear whether this fund will actually generate additional resources for climate change adaptation.

\subsection{Fair governance}

The nature of governance within society determines the space given to social actors to participate creatively in the problem solving process and thereby establish and change institutions. The Dutch water safety institutions seem to allow for and encourage a legitimate policy and implementation process. For instance, following the example of the Room for the River project, local and regional parties will also be involved actively in the development and implementation of the various measures that are part of the Second Delta Plan. The protection of basic rights and equity also seems to be provided for: every Dutch citizen will in the same way be protected against flooding; as yet the legal safety standards will not be further differentiated. Finally, as the institutions allow for legitimate policy processes, it can be expected that they will also support responsiveness. And in line with the recently introduced strict procedures for large public projects, it can be expected that the institutions will promote accountability. 


\section{Conclusion}

The central question of this paper was to what extent the historically grown Dutch water safety institutions are prepared for climate change. Our answer to this question is twofold. Based on our assessment, the application and use of the Adaptive Capacity Wheel, we can conclude that Dutch water safety institutions do enable climate change adaptation, but only to a limited extent. They provide six important institutional strengths that are required to cope with the new challenges and develop and implement adaptation strategies, but at the same time face five important institutional weaknesses that may cause risks in particular on the long term (see Table 4.1).

Table 5.1 Institutional strengths and weaknesses of Dutch water safety institutions.

\begin{tabular}{|c|c|c|}
\hline \multirow[t]{6}{*}{ Institutional strengths } & 1. & Variety in potential adaptation strategies \\
\hline & 2. & Inclusion of local and regional partners \\
\hline & 3. & Increasing water awareness in other policy domains \\
\hline & 4. & Room for experimenting and learning \\
\hline & 5. & Entrepreneurial leadership \\
\hline & 6. & Unique arrangements to generate resources \\
\hline \multirow[t]{5}{*}{ Institutional weaknesses } & 1. & Dominant focus on technical measures of flood protection \\
\hline & 2. & Lack of improvising capacity of society \\
\hline & 3. & $\begin{array}{l}\text { Strong one-sided reliance on scientific experts regarding } \\
\text { uncertainties }\end{array}$ \\
\hline & 4. & $\begin{array}{l}\text { Lack of synergy between collaborative and entrepreneurial } \\
\text { leadership }\end{array}$ \\
\hline & 5. & $\begin{array}{l}\text { Innovative adaptation strategies lack resources and are } \\
\text { viewed as 'something extra' }\end{array}$ \\
\hline
\end{tabular}

The following six institutional strengths could be identified. First, in general, the water safety institutions allow for and encourage the development of a large variety of adaptation strategies. During the last years, the variety in ideas and policy measures, or the variety in potential adaptation strategies, has increased greatly. A second institutional strength is that the Dutch water safety institutions allow for an active involvement of local and regional (government) parties in the development and implementation of these adaptation strategies. Third, they allow for and encourage an increasing awareness of water safety issues in other policy domains, such as the policy domain of spatial planning. Fourth, Dutch water safety institutions generate room for experimenting and learning on the existing institutional path of flood prevention. Fifth, they promote entrepreneurial leadership: the Dutch water sector is well known for its ability to lead by taking action, and to realise major public works. In particular the Delta Works, closing off the sea inlets in the southwest of the Netherlands, brought the Dutch worldwide fame. Finally, the Dutch water safety institutions allow for and encourage the introduction and establishment of unique arrangements to generate resources for realising water safety. The Delta Fund is only one example of such an arrangement.

However, the same institutions face the following five institutional weaknesses, causing risks on the long term. The first institutional weakness that we have identified concerns the dominant focus on technical measures of flood prevention. As a result, despite the increasing variety of adaptation measures, the degree to which innovative ideas and strategies are actually being implemented is still rather low. As a 
consequence, there is a risk of institutional lock-in. Central here is the path dependent development of the water safety institutions. This implicates that preceding steps in a particular direction, especially those with high expenditures, direct further movement in the same direction. Rational considerations of profit and loss often lead to the decision to continue the same practice. In this way, decisions are limited by decisions made in the past. Because the development and implementation of climate adaptation strategies implies new policy practices and the crossing of sectoral borders, it requires the choice of a new institutional path (North 1990; Hall \& Taylor 1996).

The second institutional weakness concerns the improvising capacity of society. As the Dutch central government has defined flood protection as a public responsibility and has taken over the responsibility for the water safety of the Netherlands, the Dutch water sector runs the risk of continuing and even increasing the control paradox. Whereas for successful climate change adaptation it is necessary that people develop the capacity to improvise and self organize during times of crisis. The strong onesided reliance on scientific experts regarding uncertainties is the third institutional weakness. Although without advanced knowledge about land use, ocean and atmospheric processes and feedbacks and sophisticated climate models, climate change most likely would still be a non-issue, important uncertainties and ambiguities exist, which cannot be solved by scientific experts alone. Moreover, the involvement of local and regional authorities, citizen and NGOs is necessary to develop and implement tailor-made solutions.

The lack of synergy between collaborative and entrepreneurial leadership is the fourth institutional weakness that we have identified. The dominant focus on probability reduction hinders the development and institutionalisation of a more collaborative leadership style, and the development of shared and more integrated problem perceptions and solutions. Fifth and finally, although unique institutional arrangements generate resources for water safety, the Dutch water safety institutions do not generate resources for innovative and more spatial adaptation strategies. These are still viewed as 'something extra'.

To conclude, the Adaptive Capacity Wheel has proven to be a useful method and tool to assess the capacity of Dutch water safety institutions to enable climate change adaptation. For the Netherlands, to be prepared for climate change, it is thus necessary to take a new institutional path, by stimulating in particular the capacity to improvise, by investing in and by creating room for collaborative leaders, and by finding ways to generate resources for innovative measures. 


\section{Acknowledgements}

This paper has been written within the Dutch Climate Changes Spatial Planning Programme, and more specifically within the project 'Institutions for adaptation: the capacity and ability of the Dutch institutional framework to adapt to climate change' (IC12). 


\section{References}

Andersson, M. \& Mol, A.P.J. (2002). The Netherlands in the UNFCCC process - Leadership between ambition and reality. International Environmental Agreements, 2(1), 49-68.

Argyris, C. \& Schön, D.A. (1978). Organizational Learning. Addison Wesley, Reading, MA.

Arnell, N.W. (1998). Climate change and water resources in Britain. Climatic Change, 39(1), 83-110.

Biermann, F. (2007). 'Earth system governance' as a crosscutting theme of global change research. Global Environmental Change, 17(3-4), 326-337.

Bohensky, E. \& Lynam, T. (2005). Evaluating responses in complex adaptive systems: insights on water management from the Southern African Millennium Ecosystem Assessment (SAfMA). Ecology and Society, 10(1), 11.

Botchway, F.N. (2001). Good Governance: the old, the new, the principle, and the elements. Florida Journal of International Law, 13(2), 159-210.

Conant, R.C. \& Ashby, W.R. (1970). Every good regulator of a system must be a model of that system. International Journal of Systems Science, 1(2), 89-97.

Deltacommissie (2008). Samen werken met water: een land dat leeft, bouwt aan zijn toekomst. Rotterdam.

Dewulf, A., Craps, M., Bouwen, R., Taillieu, T. \& Pahl-Wostl, C. (2005). Integrated management of natural resources: dealing with ambiguous issues, multiple actors and diverging frames. Water Science \& Technology, 52(6), 115-124.

DG Water 2(008). Waterveiligheid 21 e eeuw: synthesedocument. Den Haag.

Disco, C. (2002). Remaking 'nature': the ecological turn in Dutch water management. Science, Technology and Human Values, 27(2), 206-235.

Gupta, J., Termeer, K., Klostermann, J., Meijerink, S., van den Brink, M., Jong, P. \& Nooteboom, S. (2008). Institutions for climate change: a method to assess the inherent characteristics of institutions to enable the adaptive capacity of society. IC 12 Working Document 2, Institute for Environmental Studies, Amsterdam.

Gupta, J., Termeer, K., Klostermann, J., Meijerink, S., van den Brink, M., Jong, P., Nooteboom, S. \& Bergsma, E. (Forthcoming). The Adaptive Capacity Wheel: A method to assess the inherent characteristics of institutions to enable the adaptive capacity of society. Accepted for publication in Environmental Science \& Policy.

Hall, P.A. \& Taylor, R.C.R. (1996). Political science and the three new institutionalisms. Political Studies, 64, 936-957.

Hidding, M.C. \& van der Vlist, M.J. (Eds.). (2009). Ruimte en water: planningsperspectieven voor de Nederlandse delta. Sdu, Den Haag.

Hufen, J.A.M. \& Lotze, S. (2004). PKB Ruimte voor de Rivier: organisatie en besluitvorming. Eindrapportage. QA+, Den Haag.

Huisman, P. (2004). Water in the Netherlands: managing checks and balances. Netherlands Hydrological Society (NHS), Utrecht.

Huitema, D., Mostert, E., Egas, W., Moellenkamp, S., Pahl-Wostl, C. \& Yalcin, R. (2009). Adaptive water governance: assessing the institutional prescriptions of adaptive (co-) management from a governance perspective and defining a research agenda. Ecology and Society, 14(1), 26.

Huitema, D. \& Meijerink, S.V. (Eds.). (2009). Water policy entrepreneurs: a research companion to water transitions around the globe. Edward Elgar, Cheltenham. 
Huxham, C. \& Vangen, S. (2005). Managing to collaborate. Routledge, London.

IPCC (2007). Climate Change 2007: Synthesis Report - An Assessment of the Intergovernmental Panel on Climate Change. Valencia, Spain.

Lintsen, H.W. (2002). Two centuries of central water management in the Netherlands. Technology and Culture, 43(3), 549-568.

Ludwig, F., Kabat, P., van Schaik, H. \& van der Valk, M. (Eds.). (2009). Climate change adaptation in the water sector. Earthscan, London.

March, J.G. \& Olsen, J.P. (1989). Rediscovering institutions: the organizational basis of politics. The Free Press, New York.

Meijerink, S.V. (2004). Rivierbeheer als leerproces: een tussentijdse evaluatie van het procesontwerp voor de PKB Ruimte voor de Rivier. Bestuurswetenschappen, 58(5), 406427.

Meijerink, S.V. (2008). Instituties voor adaptatie. Presentation at Royal Haskoning, Nijmegen, November 2008.

Meijerink, S.V. \& Dicke, W.M. (2008). Shifts in the public-private divide in flood management. International Journal of Water Resources Development 24(4), 495-508.

Ministerie van Verkeer en Waterstaat, Ministerie van VROM \& Ministerie van LNV (2002). Startnotitie MER in het kader van de PKB-procedure Ruimte voor de Rivier. Den Haag.

North, D.C. (1990). Institutions, institutional change and economic performance. Cambridge University Press, Cambridge.

Orlikowski, W.J. (1996). Improvising organizational transformation over time: a situated change perspective. Information System Research, 7(1), 63-92.

Paavolaa, J. \& Adger, W.N. (2006). Fair adaptation to climate change. Ecological Economics, 56(4), 594-609.

Pahl-Wostl, C., Craps, M., Dewulf, A., Mostert, E., Tabara, D. \& Taillieu, T. (2007). Social learning and water resources management. Ecology and Society, 12(2), 5.

Raadgever, G.T., Mostert, E., Kranz, N., Interwies, E. \& Timmerman, J.G. (2008).. Assessing management regimes in transboundary river basins: do they support adaptive management? Ecology and Society, 13(1), 14.

Remmelzwaal, A. \& Vroon, J. (2000). Werken met water, veerkracht als strategie. Rijkswaterstaat RIZA (rapport nr. 2000.021), Lelystad.

Rijksoverheid (2008). Ontwerp Beleidsnota Waterveiligheid. Den Haag.

Scott, W.R. (2008). Institutions and organisations: ideas and interests (3rd ed.). Sage, Thousand Oaks.

Tanaka, S.K., Zhu, T., Lund, J. R., Howitt, R. E., Jenkins, M. W., Pulido, M. A., et al. (2006). Climate warming and water management adaptation for California. Climatic Change, 76(3-4), 361-387.

ten Heuvelhof, E., de Bruijn, H., de Wal, M., Kort, M., van Vliet, M., Noordink, M., et al. (2007). Procesevaluatie totstandkoming PKB Ruimte voor de Rivier: Berenschot.

Termeer, C.J.A.M. (2009). Water professionals and public leadership. Irrigation and Drainage, 58, S212-S216.

Termeer, C.J.A.M. \& Meijerink, S.V. (2009). Klimaat bestendig of klimaat neutraal bestuur? Een essay over het adaptief vermogen van instituties. Raad voor Verkeer en Waterstaat, Den Haag. 
Termeer, C.J.A.M. (2010). Governance of water safety and flood protection. Paper presented at the European Water Governance Conference: Challenges for Economics, Law, and Spatial Planning. Utrecht, University of Utrecht, 28 January 2010.

van de Ven, G.P. (2004). Man-made lowlands: history of water management and land reclamation in the Netherlands. Stichting Matrijs, Utrecht.

van den Brink, M. (2009). Rijkswaterstaat on the horns of a dilemma. Eburon, Delft.

van den Brink, M. \& Meijerink, S.V. (2006). Implementing policy innovations: resource dependence, struggle for discursive hegemony and institutional inertia in the Dutch river policy domain. GaP Working Paper series 2006/2, Nijmegen.

van der Brugge, R., Rotmans, J. \& Loorbach, D. (2005). The transition in Dutch water management. Regional Environmental Change, 5(4), 164-176.

Verweij, M. \& Thompson, M. (Eds.). (2006). Clumsy solutions for a complex world: governance, politics and plural perceptions. Palgrave Macmillan, Basingstoke.

Weick, K.E. \& Sutcliffe, K.M. (2001). Managing the unexpected: assuring high performance in an age of complexity. Jossey-Bass, San Francisco.

Wiering, M.A. \& Driessen, P.J. (2001). Beyond the art of diking: interactive policy on river management in the Netherlands. Water Policy, 3(4), 283-296.

Wiering, M.A. \& Immink, I. (2006). When water management meets spatial planning: a policy-arrangements perspective. Environment and Planning C, 24(3), 423-438.

Woltjer, J. \& Al, N. (2007). Integrating water management and spatial planning: strategies based on the Dutch experience. Journal of the American Planning Association, 73(2), 211-222.

Young, O.R. (1991) Political leadership and regime formation: on the development of institutions in international society. International Organization, 45(3), 281-308. 


\section{Annex A Authors contact details}

Margo van den Brink (corresponding author)

Department of Planning

University of Groningen

P.O. Box 800,9700 AV Groningen, the Netherlands

Tel.+31503638646 / m.a.van.den.brink@rug.nl

\section{Catrien Termeer}

Public Administration and Policy Group

Wageningen University

P.O. Box 8130,6700 EW Wageningen, the Netherlands

Tel.+31317482907 / katrien.termeer@wur.nl

Sander Meijerink

Institute for Management Research

Radboud University Nijmegen

P.O. Box $9108,6500 \mathrm{HK}$ Nijmegen, the Netherlands

Tel. +31243611648 / s.meijerink@fm.ru.nl 